\title{
Editorial A legacy of gendered culture
}

$\mathrm{T}$

THIS EDITION of Pacific Journalism Review has a gender theme. Sex is a fundamental division in all societies; all human behaviour has a biological base. The differences between men and women often involve inequalities, and this stratification is frequently seen as due to innate characteristics present in all societies. But what we do with our biological capacities is mainly a matter of learning. Anthropologists tell us that people learn their gender roles; knowing how to be a woman or a man in any society, is culturally learned.

Historically, the diversity of traditional gender roles across the Pacific reveals many forms of gender difference. Women's status varied in the region. The complexity of cultural behaviour and belief systems, the variability in the gender divisions of labour and sociopolitical systems show there were a range of determinants of female and male activities. Men and women were treated differently and behaved differently.

Early Europeans were interested in the differences and studied native societies. Male anthropologists tended to focus on and privilege male activity whereas female anthropologists like Daisy Bates investigating aboriginal societies in Australia paid more attention to women's separate spheres and the importance of these.

Margaret Mead's (1935) classic study of three tribes in New Guinea showed that differences in gender roles are 'socially produced', not inevitable. Among the Tchambuli, women were more aggressive than men, whereas the Mundugumor were headhunters and both sexes were equally aggressive and violent. Both men and women were gentle, passive and caring among the Arapesh.

Underpinning relationships between men and women were the practices around production, consumption and exchange. In broad terms, in Melanesian societies women contributed significantly to agricultural and food production more than in Polynesia where women's main work involved making mats and cloth for both domestic and ceremonial use. In Melanesia men were more 


\section{CONTEMPORARY GENDER ISSUES}

dominant than in Polynesia where men and women often had equal genealogical status and social rank. Through their production of culturally valuable items for exchange women had considerable personal and political authority.

Gender relations in the Pacific changed through Western contact and the impact of colonisation. Women's status was diminished. Christine Gailey (1987) and Jocelyn Linnekin (1990) track the shifts in Tonga and Hawai'i. Women produced goods that served to integrate whole societies and consequently, their labour was considered more valuable than men's. Mats and tapa embodied status; they were goods used in kin rituals to validate life status changes. The introduction of imported fabric supplanted handmade cloth. Also, functions for marriage and funerals were taken over by church and state. These changes undermined women's position. Labour that had been 'socially necessary, socially organised and socially valued' was now relegated to the domestic sphere. Men took control of production for the expanding market economy. Where women had autonomy in sexual liaisons, this was deemed shameful by Christian missionaries. Traditionally, lactating mothers refrained from sexual relations. This form of birth control ended when missionaries forbade seclusion and sexual availability became a wifely duty. The increase in childbearing made women dependent on men.

The emergence of new patterns of gender relations that followed European practices gradually spread throughout the Pacific and became the dominant relations, particularly in the settler societies of Australia and New Zealand. The contributions to this edition of PJR reflect the legacy of the colonial experience and the imposition of the gendered culture, and the role the media plays in reproducing men's domination and women's subordination.

In 'Man-made news', Judy McGregor writes about the participation and status of women in the media. She remarks on the top political positions in New Zealand currently held by women - the Prime Minister, Speaker of the House of Representatives, the Chief Justice and the Governor General - and how this pre-eminence does not reflect women's overall participation in public life. Women are under-represented in public life and in media organisations in terms of 'allocative control'. Men shape serious news which reflects their interests while women predominate in editing 'soft' news outlets such as community newspapers and magazines. McGregor argues for a female perspective in the influential 'hard' news outlets.

In our cover cartoon, a female protagonist wears a colander for a helmet. This protection in a futile tilting exercise symbolises the way her behaviour 6 PACIFIC JOURNALISM REVIEW 12 (1) 2006 
is defined in domestic terms. This is a problem that female politicians encounter in Australia and New Zealand. Cathy Jenkins and Heather Devere and Sharyn Graham Davies explore the way female politicians' personal lives become a feature of their political life. The media is fascinated with their appearance, and their intimate relationships particularly whether they conform to traditional wife-and-mother roles. Jenkins refers to media preoccupation with the sex lives of female politicians, particularly those who are single and childless. This has echoes in the way Helen Clark's childlessness has been made an issue in New Zealand political campaigns. Typically, her success as a politician means the media depict her as having masculine qualities. Devere and Graham see the media portraying Clark as a 'domineering, unfeminine, arrogant control-freak...and the Labour Government as a social engineering 'nanny state' ruled by a feminist cabal'. The media framing of her Government's attempt to promote and support working mothers in 2005 seems to bear out this claim. The media coverage of the policy ran it as antifamily.

In another contribution that looks at the way the political system affects women's social life, Rae Nicholl considers possible reform to the electoral system in Fiji to encourage greater representation of women. Although the struggle for women to have a political voice is a global issue, the gender gap in Fiji politics is not a matter of interest for Fiji media. Racial divisions in politics are the issues that excite the media.

In Australian media, sports stories have overwhelmingly been stories about male athletes. Dianne Jones updates her research into how Australian media cover sports stories about women athletes. Jones compared ABC News Online coverage in 2000 with 2005 and found male dominance had eroded. In 2005 there were more graphics and more lead stories about women. This did not match the gender medal tally. In fact, Jones comments that the big stories about women focused on failure rather than success. Hurdler Janine Pittman's injury was an on-going concern which highlighted her toughness and determination. Conversely, the sensation over rower Sally Robbins' collapse during the eights race was a story about her letting the side down through her lack of tenacity, illustrating that the frequency of content is not necessarily a measure of regard for women's sport. Jones warns that portrayals of women as 'tearful, passive participants ... may give credence to sexist notions that women "can't cut it" in sport because they are physically and emotionally 


\section{CONTEMPORARY GENDER ISSUES}

more delicate and less competitive and aggressive than men'. Janine Little draws on the way the media relies on cultural understandings of what it is to be female and Australian in high profile news stories. Shapelle Corby's beauty and youth seduced both the media and public to support her. In contrast, Lindy Chamberlain was depicted as a she-devil baby killer.

Yvonne Densem examines the gender imbalance in journalism courses and investigates how young men view journalism and what might attract them to train as journalists. Some informants based their impressions of journalism on journalists who are visible and because they do not identify with them, they do not see it as a job for men. Many concluded that journalism is not 'blokey', meaning by this 'masculine, self-confident, staunch but not necessarily macho'. The blokey areas are sports and war reporting. Those with a more positive view of journalism see the role of a journalist is to inform and investigate. Ideally Densem's findings point to future journalists as having a strong sense of inquiry, reflection and being non-sexist rather than blokey.

Two commentaries expand on the themes in articles. Pru Goward's polemic against a newspaper culture hostile to women where male hegemony is accepted as natural and normal sees pressure for change coming from the creation of women's newspaper groups and optimistically, a 'critical mass' of young women making demands on the system.

McGregor's concerns about the gender division of labour in the industry parallel those of the Global Media Monitoring Project which aims to give a international overview of gender content in news. Anna Turley reports that stories about economics and politics are dominated by men and written by male reporters. Women feature in 'soft' news, written by female reporters. The greater awareness of patterns of representation generated by the survey has been a useful tool to employ in dialogue for change with media practitioners and policy-makers.

McGregor, Goward and Turley all recognise that women's under-representation in the media and in media organisations reflects their status in wider society. But as more women enter social production and get their demands implemented in the public sector, it will become increasingly difficult for the media to downgrade them by relegating them to a subordinate role defined by their association with the private domestic sphere.

IN THE media commentary subtheme for the edition, Philip Cass-writing from both South Pacific and Middle East experience- looks at the impact of 
the anti-Muslim cartoons published in Denmark. Cass is interested in the way the controversy over the cartoons signifies the centrality of religion in the Muslim world which is misunderstood in the West.

Trevor Cullen, writing about the spread of HIV/AIDS in Papua New Guinea, suggests that one of the big problems in containing the epidemic relates to low social status for women. Sex is a taboo subject. This creates a difficulty for public campaigns wanting to change sexual practices. Cullen looks to Government initiatives to confront the problem.

The editors would like to thank all contributors and reviewers for their contribution to this edition.

\section{Dr Janet Bedggood}

Allison Oosterman

AUT University

\section{References}

Gailey, C.W. (1987). Kinship to kingship: Gender hierarchy and state formation in the Tongan islands. Austin: University of Texas Press.

Linnekin, J. (1990). Sacred queens and women of consequence: Rank, gender, and colonialism in the Hawai'ian islands. Ann Arbor: University of Michigan Press.

Mead, M. (1935). Sex and temperament in three primitive societies. New York: William Morrow \& Co. 